\title{
Microsurgical resection versus stereotactic guided ommaya reservoir drainage of cystic craniopharyngioma
}

\begin{abstract}
Background: Craniopharyngioma is often associated with cystic components. Although these tumors are histologically benign, recurrence rates up to $57 \%$ have been reported even after surgical gross total resections, due to their invasiveness.

Objective: To compare the outcome of invasive and less invasive surgeries of cystic craniopharyngioma.

Methods: This study included 20 patients diagnosed and managed in Al-azhar university hospitals and Al-Mansoura university hospital between May 2015 and April 2017. 10 patients were treated by surgical modalities, 10 Patients were treated by a less invasive maneuver by superior fenestration and insertion of ommaya reservoir. The craniopharyngioma was predominately cystic.

Results: Ommaya reservoir insertion and drainage of cystic craniopharyngiomas is safe and effective for symptom relief and might be associated with a better outcome than microsurgical treatment.
\end{abstract}

Volume 8 Issue I - 2018

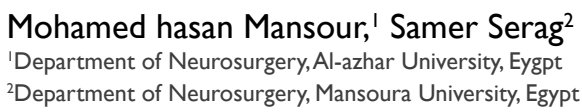

'Department of Neurosurgery, Mansoura University, Egypt

Correspondence: Mohamed hasan Mansour, Department of Neurosurgery, Al-azhar University, Cairo, Eygpt,Tel I00I256079 Emailmohamedhasanmansour@gmail.com, islamneuro@yahoo. com

Received: November II, 2017 | Published: February 02, 2018

\section{Introduction}

Craniopharyngiomas (CPs) are benign epithelial tumors that develop along the hypothalamus-hypophyseal axis and were first described by Jakob Erdheim in 1904. These tumors have represented a challenge for surgeons since the rise of modern neurosurgery.

These tumors are located close to the visual apparatus, hypothalamus, pituitary stalk, 3rd ventricle, and vasculature from the circle of Willis. The proximity of the tumor and its adherence to these critical structures makes complete microsurgical removal without neurological deterioration difficult. ${ }^{2}$ Craniopharyngioma is often associated with cystic components. ${ }^{3}$ Although these tumors are histologically benign, recurrence rates up to $57 \%$ have been reported even after surgical gross total resections, due to their invasiveness. ${ }^{4}$

Microsurgical resection is usually considered the treatment of choice in these patients. ${ }^{5}$ Alternatively, minimally invasive cyst aspiration alone or in combination with intracavitary irradiation or chemotherapy has been advocated. ${ }^{6}$ In order to overcome the limitations of aspiration alone (i.e., risk of early cystic recurrences), implantation of a shunt catheter, allowing permanent "internal drainage" of the cystic contents into cerebrospinal fluid, has been recommended by some authors.

So we conducted the current study. We here analyze and compare tumor control rates and outcome of cystic craniopharyngiomas treated with either open microsurgical resection or stereotactic guided ommaya reservoir drainage as a minimal invasive method.

\section{Aim of the work}

To compare the outcome of invasive and less invasive surgeries of cystic Craniopharyngioma (Table 1).

\section{Patients and methods}

This study included 20 patients diagnosed and managed in Al-azhar university hospitals and Al-Mansoura university hospital between May
2015 and April 2017. 10 patients were treated by surgical modalities (group A), 10 Patients were treated by a less invasive maneuver by superior fenestration and insertion of ommaya reservoir (group B). The craniopharyngioma was predominately cystic. Informed consent was obtained according to regulations of ethical committee.

\section{Laboratory protocol}

We did some blood tests for both groups as preoperative investigations $(\mathrm{CBC}$, Liver and Kidney function, Blood sugar level and $\mathrm{Na} / \mathrm{K}$ level) for both groups. For group $\mathrm{B}$ we analyzed the aspirated fluid.

\section{Endocrinological Protocol}

Hormonal profile was also measured Preoperatively (TSH, LH, FSH, Prolactin, GH and cortisol) to detect effect on pituitary gland and 6 weeks postoperatively.

\section{Radiology protocol}

All patient had Computed tomography (CT scan) and also had magnetic resonance imaging (MRI). CT was done early and late postoperative as a follow up method.

\section{Ophthalmological Protocol}

Ophthalmological tests included visual acuity measurements and perimetry of the visual field preoperatively and 6 weeks after treatment, evaluated by an ophthalmologist blinded to the mode of treatment.

\section{Surgical procedure}

Group A were selected for surgical management, trans-sphenoidal and transcranial (transcallosal and pterional) approaches were selected. For Group B which was selected for ommaya reservoir insertion, Stereotactic (by leksell frame) surgery and contrastenhanced CT was performed under local anaesthesia. Target was selected $5 \mathrm{~mm}$ above the lowest cut, where the cyst starts. In all 
group B patients, the site of the burr hole was just in front of the coronal suture and $2-3 \mathrm{~cm}$ lateral to the midline. Ommaya catheter was inserted into the predetermined target, along the recommended trajectory to avoid any bleeding, slowly sliding the stereotactic needle to facilitate capsular fenestration and adjusting the length of ommaya catheter. The perforated part of the catheter was inserted into the cyst cavity. The catheter was connected to the reservoir. After skin closure, slow but complete aspiration of the cyst was performed. The cystic fluid was dark brown in colour, it was full of crystals that shimmered in the light and it was sent for cytological examination. CT scan was obtained in the following 6 hours.

Table I 20 cases with cystic craniopharyngioma

\begin{tabular}{|c|c|c|c|c|c|c|c|c|}
\hline Patient no. & $\begin{array}{l}\text { Age(ys) } \\
\text { /sex }\end{array}$ & Clinical & Examination & Laboratory & Imaging & Management & Outcome & Complications \\
\hline \multicolumn{9}{|l|}{ Group A } \\
\hline I & $2 \mathrm{I} / \mathrm{F}$ & $\begin{array}{l}\text { Headache, } \downarrow \text { vision, } \\
\text { visual field defect, } \\
\text { growth retardation, } \\
\text { amenorrhea. }\end{array}$ & $\begin{array}{l}\text { Bitemp. Hemianopia, } \\
\downarrow \text { vision }\end{array}$ & $\downarrow \mathrm{FSH}, \mathrm{LH}$ & $\begin{array}{l}\text { Cystic, Enhanced, } \\
\text { Calcified wall. }\end{array}$ & $\begin{array}{l}\text { Surgical } \\
\text { (transsphenoidal) }\end{array}$ & $\begin{array}{l}\text { Improved } \\
\text { vision }\end{array}$ & - \\
\hline 2 & $5 \mathrm{I} / \mathrm{F}$ & $\begin{array}{l}\text { Headache, } \downarrow \text { vision, } \\
\text { visual field defect. }\end{array}$ & $\begin{array}{l}\text { Papilledema, left } \\
\text { temp. H., } \downarrow \text { vision }\end{array}$ & $\mathrm{N}$ & Cystic, Enhanced & $\begin{array}{l}\text { Surgical } \\
\text { (transsphenoidal) }\end{array}$ & - & $\begin{array}{l}\text { DI, DCL Death } \\
\text { after I } 5 \text { days }\end{array}$ \\
\hline 3 & I3/F & $\downarrow$ vision & $\downarrow$ vision & $\mathrm{N}$ & $\begin{array}{l}\text { Cystic, Enhanced, } \\
\text { Calcified wall, } \\
\text { hydrocephalus. }\end{array}$ & Surgical (pterional) & $\begin{array}{l}\text { Improved } \\
\text { vision }\end{array}$ & DI \\
\hline 4 & $16 / M$ & $\begin{array}{l}\text { Headache, } \downarrow \text { vision, } \\
\text { visual field defect, } \\
\text { growth retardation }\end{array}$ & $\begin{array}{l}\text { Stunted growth, } \\
\downarrow \text { vision }\end{array}$ & $N$ & Cystic, Enhanced. & Surgical (pterional) & $\begin{array}{l}\text { Improved } \\
\text { vision }\end{array}$ & $\mathrm{SDH}$ \\
\hline 5 & $50 / F$ & $\begin{array}{l}\text { Headache, } \downarrow \text { vision, } \\
\text { visual field defect. }\end{array}$ & $\downarrow$ vision & $\uparrow$ prolactin & Cystic, Enhanced. & $\begin{array}{l}\text { Surgical } \\
\text { (transsphenoidal) }\end{array}$ & $\begin{array}{l}\text { Improved } \\
\text { vision }\end{array}$ & $\begin{array}{l}\text { Transient CSF } \\
\text { rhinorrhea }\end{array}$ \\
\hline 6 & $40 / M$ & $\begin{array}{l}\downarrow \text { vision, visual field } \\
\text { defect, obesity, } \\
\text { fatigability, loss of } \\
\text { lipido, sleep disorder }\end{array}$ & Overweight, $\downarrow$ vision. & $\downarrow \mathrm{FSH}, \mathrm{LH}$ & $\begin{array}{l}\text { Cystic,Enhanced, } \\
\text { Calcified wall. }\end{array}$ & Surgical (pterional) & $\begin{array}{l}\text { Improved } \\
\text { vision }\end{array}$ & - \\
\hline 7 & $45 / M$ & $\begin{array}{l}\text { Headache, } \downarrow \text { vision, } \\
\text { visual field defect. }\end{array}$ & $\begin{array}{l}\text { Bitemp. Hemianopia, } \\
\downarrow \text { vision }\end{array}$ & $\mathrm{N}$ & Cystic, Enhanced. & Surgical (pterional) & $\begin{array}{l}\text { Improved } \\
\text { vision }\end{array}$ & - \\
\hline 8 & $\mathrm{II} / \mathrm{F}$ & $\begin{array}{l}\text { Headache, } \downarrow \text { vision, } \\
\text { visual field defect, } \\
\text { growth retardation, } \\
\text { polyuria }\end{array}$ & $\begin{array}{l}\text { Bitemp. Hemianopia, } \\
\downarrow \text { vision }\end{array}$ & $N$ & $\begin{array}{l}\text { Cystic, Enhanced, } \\
\text { Calcified wall. }\end{array}$ & Surgical (pterional) & $\begin{array}{l}\text { Improved } \\
\text { vision }\end{array}$ & DI \\
\hline 9 & 9/F & $\begin{array}{l}\text { Headache, } \downarrow \text { vision, } \\
\text { visual field defect. }\end{array}$ & $\downarrow$ vision & $\downarrow \mathrm{FSH}, \mathrm{LH}$. & $\begin{array}{l}\text { Cystic, Enhanced, } \\
\text { Calcified wall, } \\
\text { hydrocephalus. }\end{array}$ & Surgical (pterional) & - & $\begin{array}{l}\text { DI, DCL } \\
\text { Wakness, death } \\
\text { after } 5 \text { days. }\end{array}$ \\
\hline 10 & $17 / M$ & $\begin{array}{l}\text { Headache, vomiting, } \\
\downarrow \text { vision, visual field } \\
\text { defect, obesity, } \\
\text { fatigability, behavioral } \\
\text { disorders, seizures. }\end{array}$ & Overweight. & $\downarrow \mathrm{FSH}, \mathrm{LH}$. & $\begin{array}{l}\text { Cystic, Enhanced, } \\
\text { Calcified wall, } \\
\text { hydrocephalus. }\end{array}$ & Surgical (pterional) & $\begin{array}{l}\text { Improved } \\
\text { vision }\end{array}$ & DI \\
\hline \multicolumn{9}{|l|}{ Group B } \\
\hline 11 & $50 / M$ & $\begin{array}{l}\text { Headache, } \downarrow \text { vision, } \\
\text { visual field defect, } \\
\text { fatigability, loss of } \\
\text { lipido, sleep and } \\
\text { behavioral disorders. }\end{array}$ & Papilledema, $\downarrow$ vision & $\downarrow \mathrm{TSH}, \mathrm{FSH}, \mathrm{LH}$, & $\begin{array}{l}\text { Cystic, Enhanced, } \\
\text { Calcified wall, } \\
\text { hydrocephalus. }\end{array}$ & $\begin{array}{l}\text { Ommaya reservoir } \\
\text { insertion }\end{array}$ & $\begin{array}{l}\text { Improved } \\
\text { vision }\end{array}$ & $\begin{array}{l}\text { Sliding of } \\
\text { catheter end }\end{array}$ \\
\hline 12 & $8 / F$ & $\begin{array}{l}\text { Headache, vomiting, } \\
\downarrow \text { vision. }\end{array}$ & $\begin{array}{l}\text { Papilledema, } \\
\text { concentric visual } \\
\text { field, } \downarrow \text { vision }\end{array}$ & $\mathrm{N}$ & $\begin{array}{l}\text { Cystic, Enhanced, } \\
\text { Calcified wall, } \\
\text { hydrocephalus. }\end{array}$ & $\begin{array}{l}\text { Ommaya reservoir } \\
\text { insertion }\end{array}$ & $\begin{array}{l}\text { Improved } \\
\text { vision }\end{array}$ & - \\
\hline 13 & $38 / F$ & $\begin{array}{l}\downarrow \text { vision, visual } \\
\text { field, galactorrhea, } \\
\text { loss of lipido, } 2 \text { ry } \\
\text { amenorrhea. }\end{array}$ & 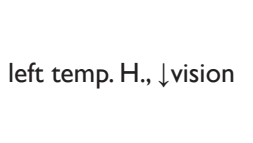 & $\begin{array}{l}\downarrow \mathrm{FSH}, \mathrm{LH} . \\
\uparrow \text { Prolactin }\end{array}$ & Cystic, Enhanced. & $\begin{array}{l}\text { Ommaya reservoir } \\
\text { insertion }\end{array}$ & $\begin{array}{l}\text { Improved } \\
\text { vision }\end{array}$ & - \\
\hline 14 & I0/F & $\begin{array}{l}\text { Headache, } \downarrow \text { vision, } \\
\text { visual field defect. }\end{array}$ & $\begin{array}{l}\text { Bitemp. Hemianopia, } \\
\downarrow \text { vision }\end{array}$ & $N$ & Cystic, Enhanced. & $\begin{array}{l}\text { Ommaya reservoir } \\
\text { insertion }\end{array}$ & $\begin{array}{l}\text { Improved } \\
\text { vision }\end{array}$ & $\begin{array}{l}\text { Displaced } \\
\text { catheter end }\end{array}$ \\
\hline 15 & $36 / M$ & $\begin{array}{l}\text { Headache, } \downarrow \text { vision, } \\
\text { visual field defect. }\end{array}$ & $\begin{array}{l}\text { Bitemp. Hemianopia, } \\
\downarrow \text { vision }\end{array}$ & $\mathrm{N}$ & Cystic, Enhanced. & $\begin{array}{l}\text { Ommaya reservoir } \\
\text { insertion }\end{array}$ & $\begin{array}{l}\text { Improved } \\
\text { vision }\end{array}$ & - \\
\hline 16 & $50 / F$ & $\begin{array}{l}\text { Headache, } \downarrow \text { vision, } \\
\text { visual field defect. }\end{array}$ & left temp. $H ., \downarrow$ vision & $\mathrm{N}$ & Cystic, Enhanced. & $\begin{array}{l}\text { Ommaya reservoir } \\
\text { insertion }\end{array}$ & $\begin{array}{l}\text { Improved } \\
\text { vision }\end{array}$ & - \\
\hline
\end{tabular}


Table Continued..

\begin{tabular}{|c|c|c|c|c|c|c|c|c|}
\hline Patient no. & $\begin{array}{l}\text { Age(ys) } \\
\text { /sex }\end{array}$ & Clinical & Examination & Laboratory & Imaging & Management & Outcome & Complications \\
\hline 17 & $5 / F$ & $\begin{array}{l}\text { Headache, } \downarrow \text { vision, } \\
\text { visual field defect, } \\
\text { polyuria }\end{array}$ & Underweight, $\downarrow$ vision & $\mathrm{N}$ & $\begin{array}{l}\text { Cystic, Enhanced. } \\
\text { Calcified wall, } \\
\text { hydrocephalus. }\end{array}$ & $\begin{array}{l}\text { Ommaya reservoir } \\
\text { insertion }\end{array}$ & $\begin{array}{l}\text { Improved } \\
\text { vision }\end{array}$ & - \\
\hline 18 & $7 / M$ & $\begin{array}{l}\text { Headache, vomiting, } \\
\downarrow \text { vision, visual field } \\
\text { defect, growth } \\
\text { retardation. }\end{array}$ & $\downarrow$ vision & $\mathrm{N}$ & $\begin{array}{l}\text { Cystic, Enhanced. } \\
\text { Calcified wall, } \\
\text { hydrocephalus. }\end{array}$ & $\begin{array}{l}\text { Ommaya reservoir } \\
\text { insertion }\end{array}$ & $\begin{array}{l}\text { Improved } \\
\text { vision }\end{array}$ & $\begin{array}{l}\text { Disconnected } \\
\text { catheter end }\end{array}$ \\
\hline 19 & $8 / M$ & $\begin{array}{l}\text { Headache, } \downarrow \text { vision, } \\
\text { visual field defect. }\end{array}$ & $\begin{array}{l}\text { Bitemp. Hemianopia, } \\
\downarrow \text { vision }\end{array}$ & $\mathrm{N}$ & Cystic. & $\begin{array}{l}\text { Ommaya reservoir } \\
\text { insertion }\end{array}$ & $\begin{array}{l}\text { Improved } \\
\text { vision }\end{array}$ & - \\
\hline 20 & $32 / F$ & $\begin{array}{l}\text { Headache, } \downarrow \text { vision, } \\
\text { visual field defect, } \\
\text { galactorrhea, obesity, } \\
\text { fatigability, } 2 \text { ry } \\
\text { amenorrhea, sleep and } \\
\text { behavioral disorders, } \\
\text { polyuria. }\end{array}$ & $\begin{array}{l}\text { Left 6th palsy, } \\
\text { overweight, } \downarrow \text { vision }\end{array}$ & $\begin{array}{l}\downarrow \mathrm{FSH}, \mathrm{LH} . \\
\uparrow \text { Prolactin }\end{array}$ & $\begin{array}{l}\text { Cystic, Enhanced. } \\
\text { Calcified wall, } \\
\text { hydrocephalus. }\end{array}$ & $\begin{array}{l}\text { Ommaya reservoir } \\
\text { insertion }\end{array}$ & - & DI, DCL. \\
\hline
\end{tabular}

\section{Results}

\section{Population}

8 males $(40 \%)$ and 12 females $(60 \%)$ were the overall patients included in this study, the peak incidence of our patients were in the $1^{\text {st }}$ decade of life (30\%), and (55\%) of our patients were younger than 30 years, ages ranging between 5 and 51 years, with a mean age of 25.85 years.

\section{Clinical presentation}

The most common clinical presentation was decrease visual acuity, in 20 cases $(100 \%)$ followed by visual field defect in 18 cases $(90 \%)$ and Headache in 17 cases $(85 \%)$.

\section{Hormonal profile}

7 cases showed decreased TSH and LH level (35\%), 3 cases showed increase prolactin level (15\%).

\section{Radiological findings}

All cases were cystic (100\%) and 19 cases were enhanced (95\%), 11 cases were calcified wall (55\%), 8 cases presented radiologically by hydrocephalus $(40 \%)$.

\section{Surgical approaches}

All group A patients were managed surgically by different approaches, 2 cases transhenoidal $(10 \%), 7$ cases pterional $(35 \%)$, 1 case transcallosal (5\%). All group B patients were managed by ommaya reservoir insertion

\section{Outcome}

In group A patients 8 of 10 patients reported improved visual acuity postoperative. In group B patient 9 of 10 patients reported improved visual acuity (Figure 1).

\section{Complications}

In group $\mathrm{A}$, the most common complication was diabetes insipidus in 5 cases, disturbed conscious level in 2 cases, death in 2 cases one after 15 days postoperative and another one 5 days postoperative, subdural hematoma in 1 case and transient CSF rhinorrhea in 1 case (Figure 2).

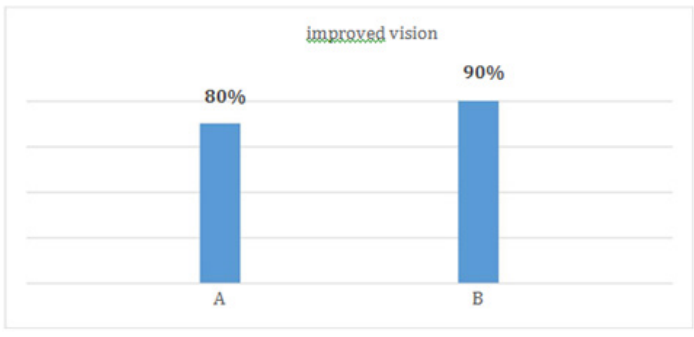

Figure I Outcome in both groups.

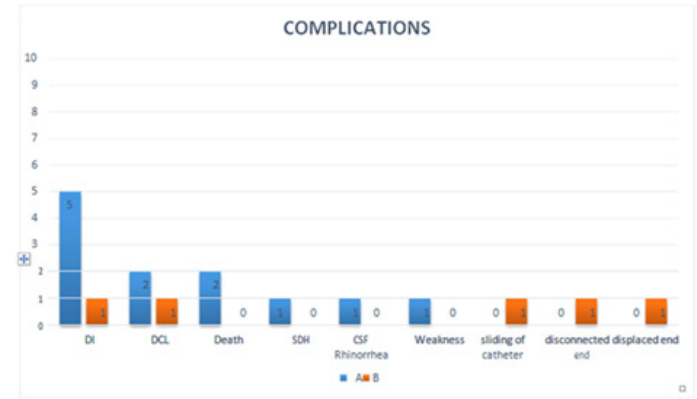

Figure 2 Complications in both groups.

In group $\mathrm{B}$, the most common complication was sliding of the catheter end in 1 case (Figure 3), diabetes insipidus in 1 case, disturbed conscious level in 1 case, disconnected catheter end in 1 case (Figure 4 ) and displaced catheter end in 1 case (Figure 5).

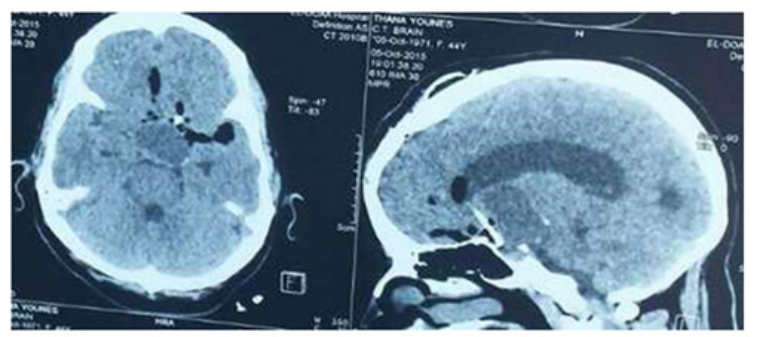

Figure 3 Sliding of the distal catheter end anterior to the cyst due to its calcified wall and was corrected by introducing the needle first to open the calcified wall then the stylet. 


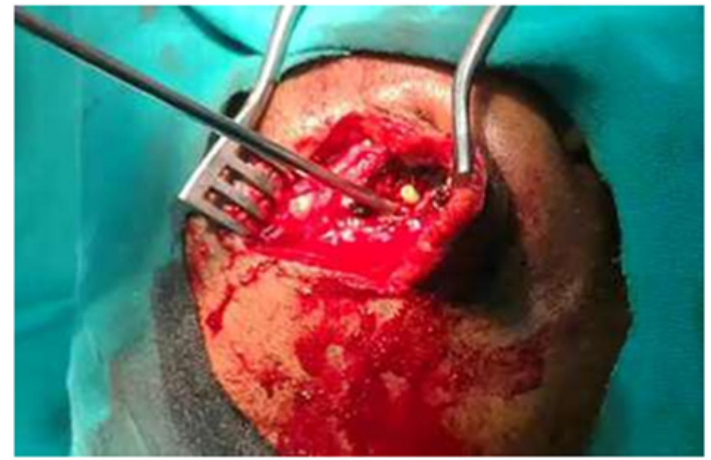

Figure 4 Disconnected catheter end of ommaya reservoir and was corrected.

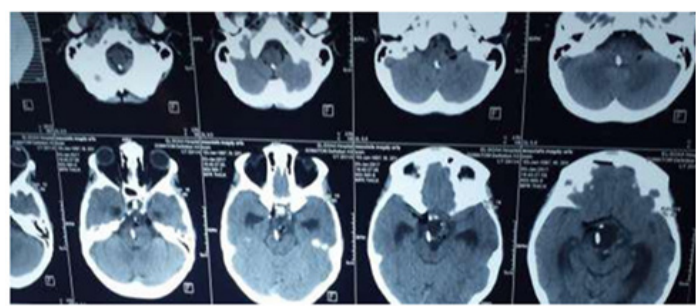

Figure 5 Displaced the distal catheter end passing through the pons till below the foramen magnum at the $4^{\text {th }}$ ventricle and was corrected.

\section{Discussion}

DO NO HARM TO YOUR PATIENTS, this is one of the ten Hippocratic medical principles, beside the religious instructions regarding respection of the human beings. So in this study we are trying to find the best strategy for managing cystic craniopharyngioma.

In our study, the peak incidence of our patients were in the $1^{\text {st }}$ decade of life $(30 \%)$. In our study, The most common clinical presentation was decrease visual acuity. In Moussa et $a .^{8}$ raised intracranial pressure and visual changes were the main presenting symptoms andhormonal changes were observed in some patients. All cases were of cystic type, some cases were enhanced, some of calcified wall, some cases presented radiologically by hydrocephalus which needed VP shunt.

In group A patients 8 of 10 patients reported improved visual acuity postoperative. In group B patient 9 of 10 patients reported improved visual acuity. There is two patients died at group B. All group A patients were managed surgically by different approaches, many different complications were occurred, diabetes insipidus, death, CSF Rhinorrhea and weakness.

Group B patients were managed by by ommaya reservoir insertion, complications were diabetes insipidus in one case only, another case was complicated by sliding of the distal catheter end and crossed the brainstem till reaching the $4^{\text {th }}$ ventricle (Figure 5) but after follow up $\mathrm{CT}$ the patient was reoperated and correction of the length of catheter was done to be placed in the cyst. Another case was complicated by disconnection of the catheter (Figure 4) from reservoir and when we decided aspiration from reservoir, no fluid came, so we reoperated and the complication was corrected. Another case was complicated by sliding of the distal catheter end anterior to the cyst due to its calcified wall (Figure 3) and it was corrected introducing the needle first to open the calcified wall then the stylet of the stereotactic system.

So, Complications occurred during microsurgical treatment (group A) were severe sometimes like death and weakness and diabetes insipidus and also irreversible but Complications occurred during ommaya reservoir insertion were less severe and mostly reversible.

In Rachinger et al. ${ }^{9}$ Stereotactic bidirectional drainage of cystic craniopharyngiomas is effective and provides a better endocrinological outcome than conventional microsurgery. For stereotactic drainage, a catheter was implanted, allowing both permanent upstream (into ventricular spaces) and downstream (into prepontine cistern) drainage. We recommend ommaya as an optional management in de novo cases but strongly recommended in recurrent cases due to the presence of adhesions so incidence of complications is high.

Ommaya reservoir insertion is not a final treatment as it is not only for cystic fenestration and aspiration but acts like a stent for repeated aspiration if needed and follow up of tumor activity by measuring levels of LDH and CAE of the aspirated cystic fluid, to advise radiotherapy or not. The Ommaya itself could catheter by act as a stent, creating a tract allowing gradual drainage of cyst fluid and stabilization without necessitating any further interventions in selected cases. ${ }^{4,10}$

In Moussa et al. ${ }^{8} 73 \%$ patients did not develop any recollection of the cyst and showed significant clinical improvement. The only possible explanation is that the part of the catheter of the ommaya reservoir system, with holes in, has established communication between the cyst and the CSF spaces around it after the collapse of the cyst with no adverse effect on the patient at any time. Ten (19\%) patients needed reaspiration every 6 months and four $(8 \%)$ patients showed rapid recollection of cystic fluid and were treated with intracystic bleomycin.

\section{Conclusion}

Ommaya reservoir insertion and drainage of cystic craniopharyngiomas is safe and effective for symptom relief and might be associated with a better outcome than microsurgical treatment.

\section{Acknowledgements}

The authors wish to thank all staff members of neurosurgery departments at alazhr university and al Mansoura university.

\section{Conflicts of interest}

None.

\section{References}

1. Castro-Dufourny I, Carrasco R, Prieto R, et al. The first sixtyfive craniopharyngioma operations in France. Rev Neurol (Paris). 2017;173(4):180-188.

2. Fahlbusch R, Hofmann BM. Surgical management of giant craniopharyngiomas. Actaneurochirurgica. 2008;150(12):1213-1226.

3. Joki T, Oi S, Babapour B, et al. Neuroendoscopic placement of Ommaya reservoir into a cystic craniopharyngioma. Child's Nervous System. 2002;18(11):629-633.

4. Rahmathulla G, Barnett GH. Minimally invasive management of adult craniopharyngiomas: An analysis of our series and review of literature. Surg Neurol Int. 2013;4(Suppl 6):S411.

5. Mortini P, Gagliardi F, Boari N, et al. Surgical strategies and modern therapeutic options in the treatment of craniopharyngiomas. Crit Rev Oncol Hematol. 2013;88(3):514-529.

6. Kickingereder P, Maarouf M, El Majdoub F, et al. Intracavitary brachytherapy using stereotactically applied phosphorus -32 colloid for treatment of cystic craniopharyngiomas in 53 patients. $J$ Neurooncol. 2012;109(2):365-374. 
7. Schubert T, Trippel M, Tacke U, et al. Neurosurgical treatment strategies in childhood craniopharyngiomas: is less more?. Child's Nerv Syst. 2009;25(11):1419-1427.

8. Moussa AH, Kerasha AA, Mahmoud ME. Surprising outcome of ommaya reservoir in treating cystic craniopharyngioma: a retrospective study. Br J Neurosurg. 2013;27(3):370-373.
9. Rachinger W, Oehlschlaegel F, Kunz M, et al. Cystic Craniopharyngiomas: microsurgical or stereotactic treatment? Neurosurgery. 2017;80(5):733-743.

10. Chiou SM, Lunsford LD, Niranjan A, et al. Stereotactic radiosurgery of residual or recurrent craniopharyngioma, after surgery, with or without radiation therapy. Neuro-oncology. 2001;3(3):159-166. 